\title{
Review Article \\ The Endocannabinoid System and Sex Steroid Hormone-Dependent Cancers
}

\author{
Thangesweran Ayakannu, Anthony H. Taylor, Timothy H. Marczylo, \\ Jonathon M. Willets, and Justin C. Konje
}

Endocannabinoid Research Group, Reproductive Sciences Section, Department of Cancer Studies and Molecular Medicine, Robert Kilpatrick Clinical Sciences Building, University of Leicester, Leicester Royal Infirmary, P.O. Box 65, Leicester, Leicestershire LE2 7LX, UK

Correspondence should be addressed to Anthony H. Taylor; aht3@leicester.ac.uk

Received 19 July 2013; Revised 9 October 2013; Accepted 23 October 2013

Academic Editor: Heather B. Bradshaw

Copyright (c) 2013 Thangesweran Ayakannu et al. This is an open access article distributed under the Creative Commons Attribution License, which permits unrestricted use, distribution, and reproduction in any medium, provided the original work is properly cited.

\begin{abstract}
The "endocannabinoid system (ECS)" comprises the endocannabinoids, the enzymes that regulate their synthesis and degradation, the prototypical cannabinoid receptors (CB1 and CB2), some noncannabinoid receptors, and an, as yet, uncharacterised transport system. Recent evidence suggests that both cannabinoid receptors are present in sex steroid hormone-dependent cancer tissues and potentially play an important role in those malignancies. Sex steroid hormones regulate the endocannabinoid system and the endocannabinoids prevent tumour development through putative protective mechanisms that prevent cell growth and migration, suggesting an important role for endocannabinoids in the regulation of sex hormone-dependent tumours and metastasis. Here, the role of the endocannabinoid system in sex steroid hormone-dependent cancers is described and the potential for novel therapies assessed.
\end{abstract}

\section{Introduction}

Cancer is characterised by an imbalance in cell cycle regulation leading to uncontrolled cell division and reduced cell death. Previous findings, suggesting that endocannabinoids play a vital role in cell proliferation, differentiation, and/or cell survival $[1,2]$, indicate that modulation of endocannabinoid action may provide an effective novel therapy for the amelioration of cancer symptoms or provide a method for continuous chemoprevention against cancer. This review will focus on describing connections between the endocannabinoid system and sex steroid hormone-dependent cancers.

1.1. The Endocannabinoid System. Endocannabinoids and their receptors are found throughout the body: in the brain, lungs, digestive system, connective tissues, hormone releasing glands, skin/hair, bone, the immune system, and the reproductive organs. The endocannabinoid system is a multifaceted endogenous signalling arrangement that influences multiple metabolic pathways [3]. It is composed of transmembrane endocannabinoid receptors (G-protein-coupled
[CB1 and $\mathrm{CB} 2]$ receptors), their endogenous ligands (the endocannabinoids), and the proteins involved in their biosynthesis and degradation [4]. The main active ingredient of cannabis, $\Delta^{9}$-tetrahydrocannabinol $\left(\Delta^{9}\right.$-THC), mediates its effects through binding and activation of CB1 [5-7] and/or CB2 receptors $[8,9]$. Because THC and its analogues have been used in palliative treatments where they inhibit tumour cell growth [10], research dedicated to the potential role of THC and the modulation of the endocannabinoid system in cancer treatment has increased [10-12].

1.2. Endocannabinoid Synthesis and Degradation. Endocannabinoids are unsaturated fatty acid derivatives, which are mainly considered to be synthesised "on demand" from phospholipid precursors residing in the plasma membrane [13] but may also be synthesised and stored in intracellular lipid droplets and released from those stores under appropriate conditions [14]. The most well-characterised endocannabinoids are anandamide ( $N$-arachidonoylethanolamide, AEA) [15] and 2-arachidonoylglycerol (2-AG) [16], whose synthesis occurs through the action of a series of intracellular 

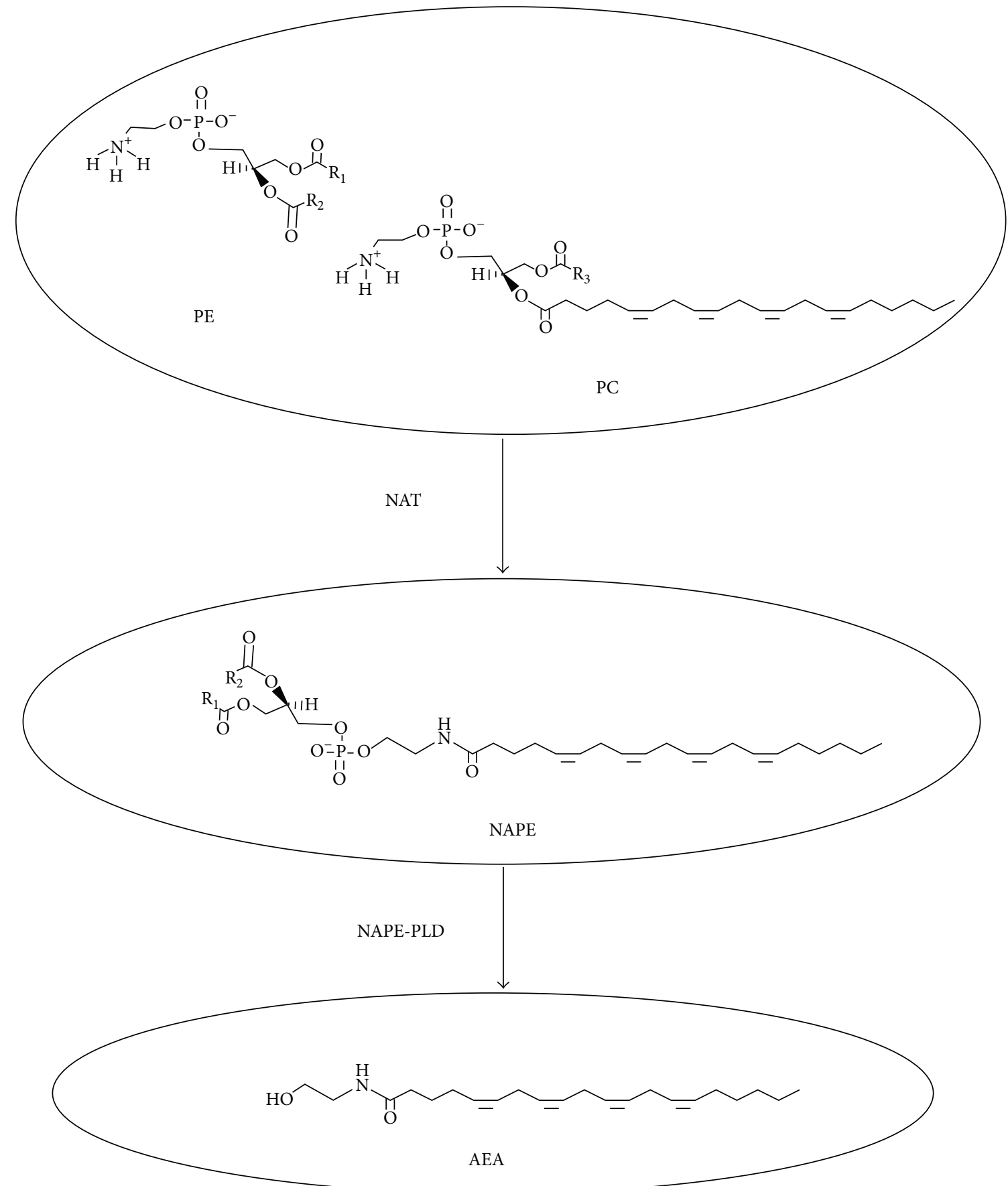

FIGURE 1: Synthesis of $N$-arachidonoylethanolamine (AEA). $N$-acyltransferase (NAT) catalyzes the transfer of arachidonic acid (AA) from phosphatidylcholine (PC) to phosphatidylethanolamine (PE) to form $N$-arachidonoyl-phosphatidylethanolamine (NAPE). NAPE is then converted into AEA in a one-step hydrolysis reaction catalyzed by the NAPE-specific phospholipase D (NAPE-PLD).

enzymes activated in response to a rise in intracellular calcium levels [17-19]. AEA was the first endogenous ligand identified for cannabinoid receptors and remains the most frequently investigated endocannabinoid [15]. AEA is produced via at least four separate pathways but the pathway that is most active in nonneuronal cells is the one where $N$ arachidonoyl phosphatidylethanolamine is directly converted to anandamide by the actions of $\mathrm{N}$-arachidonoyl phosphatidylethanolamine-specific phospholipase D (NAPE-PLD [20] (Figure 1)) that has little in common with other phospholipases [21].

The second most often studied endocannabinoid is 2-AG, which is synthesised from diacylglycerol by the sequential actions of phospholipase $\mathrm{C}$ and two calcium sensitive $s n$-2selective diacylglycerol lipases ( $\alpha$ and $\beta$ DAGL) (Figure 2) [22]. When released from cells, AEA and 2-AG act in 


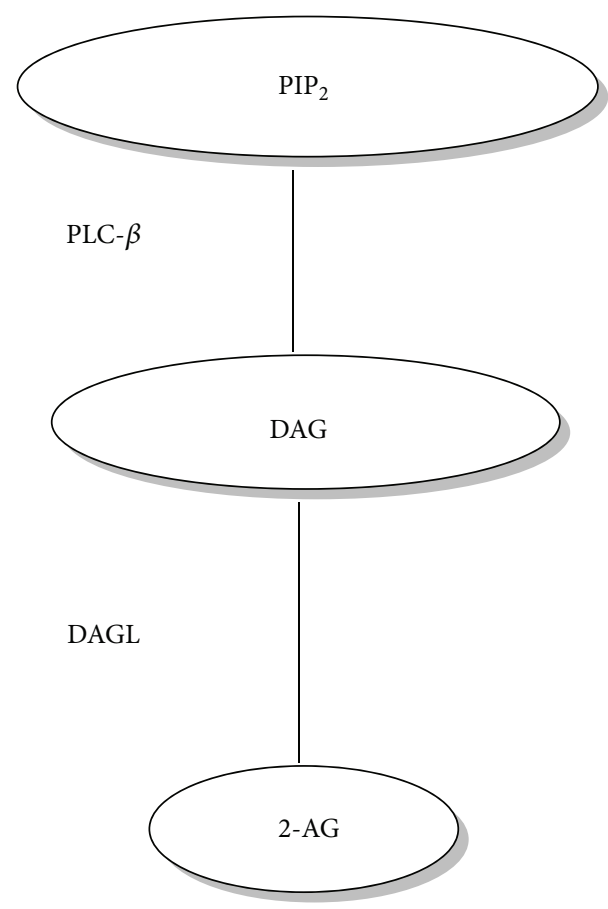

FIGURE 2: Synthesis of 2-AG. Phosphatidylinositol-4,5-bisphosphate (PIP2) is hydrolysed by phospholipase C- $\beta$ (PLC- $\beta$ ) to form diacylglycerol (DAG). The DAG is then hydrolysed to $2-\mathrm{AG}$ by diacylglycerol lipase (DAGL).

an autocrine or paracrine manner to stimulate signalling through interaction with various extracellular and intracellular receptor targets (Figure 2). To facilitate endocannabinoid reuptake and attenuate signalling, a diverse number of transport systems have been postulated, such as cellular endocytosis, simple diffusion, and specific carrier proteins [23], but none are yet proven. Both AEA and 2-AG are degraded through the action of specific enzymes; AEA is predominantly metabolised to arachidonic acid and ethanolamine by the enzyme fatty acid amide hydrolyse (FAAH-1) (Figure 3) [24] and to a lesser extent by FAAH-2 (not present in rodents). Although 2-AG is also metabolised by FAAH-1 and to a lesser extent by $\alpha, \beta$-hydrolase- 6 (ABHD6) and $\alpha, \beta$ hydrolase-12 (ABDH12), it is not metabolised by FAAH-2; the predominant enzyme involved in its degradation is monoacylglycerol lipase (MAGL) (Figure 4) $[25,26]$. Once inside the cell, AEA is considered to be moved around the cell by an intracellular FAAH-like protein (FLAT-1), that is, catalytically silent, does not bind 2-AG, and delivers it to FAAH-2 on microsomal membranes [27].

Several other endocannabinoids have been identified, including $N$-arachidonoyl-dopamine (NADA) [28], noladin ether, and virodhamine [29]. In addition, structural analogues of endocannabinoids with low affinities for cannabinoid receptors such as $N$-oleoylethanolamine (OEA), $N$-palmitoylethanolamine (PEA), $N$-stearoylethanolamine (SEA), and linoleoylglycerol have also been identified in human, rat, and mouse tissues $[30,31]$. These compounds produce an "entourage effect" through being alternative substrates for FAAH and MAGL and thereby increasing the potency of

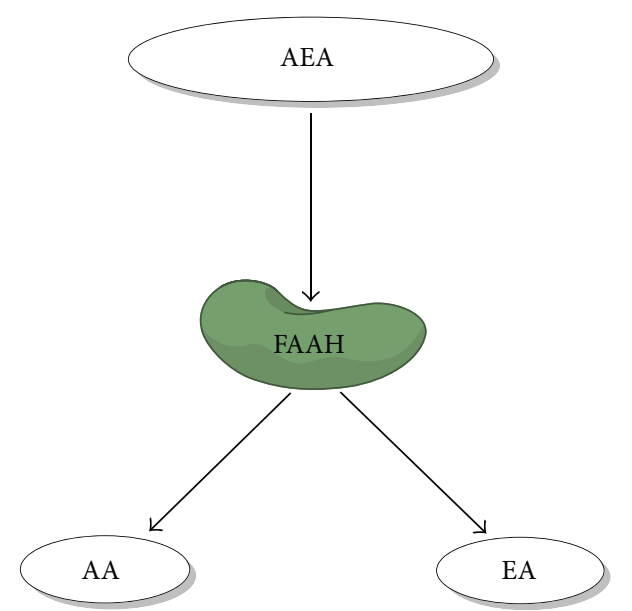

FIGURE 3: AEA is hydrolysed into arachidonic acid (AA) and ethanolamine by fatty acid amide hydrolase (FAAH).

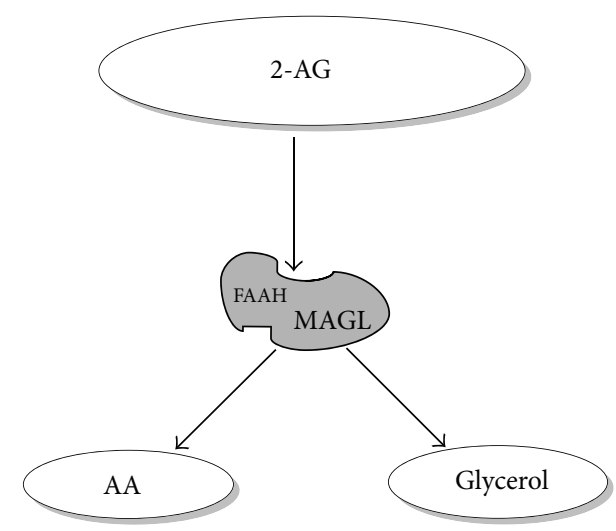

FIGURe 4: 2-AG is hydrolysed by FAAH and MAGL. As indicated by the size of the letters, MAGL is the major enzyme degrading 2-AG.

endocannabinoids, such as AEA and 2-AG whose degradation by these enzymes is inhibited $[32,33]$. Endocannabinoids may also undergo oxidative metabolism by a number of fatty acid oxygenases, such as cytochrome P450 en-zymes (CYP450) [34, 35], lipoxygenases (LOX) [36, 37], and cyclooxygenase-2 (COX-2) [38, 39]. Stimulation of CYP450s, LOXs, and COX-2 in tumour cells and inflammation sites could thus reduce the levels of naturally occurring antiproliferative and anti-inflammatory mediators $[40,41]$.

1.3. Receptors. Two subtypes of cannabinoid receptors belonging to the Gi/o family of seven trans-membrane G-protein-coupled receptors (GPCR) have been described. The first, CB1, or the central receptor was first described as being predominantly expressed in the central nervous system but is also present in a variety of peripheral tissues at much lower levels [42-44]. The second, CB2, or the spleen-type receptor was originally isolated from splenic cells and is primarily expressed in immune and blood cells, although it has also been found in various brain areas [45] and other tissues [46, 47]. Both receptors are distributed in human tissues including the brain, testis, sperm, leucocytes, placenta, fetal membranes, endothelial cells, anterior eye, pituitary gland, breast, 
and reproductive tissues [17, 48-54]. Surprisingly, they share little sequence homology, only $44 \%$ at the protein level or $68 \%$ in the trans-membrane domains, which are thought to contain the binding sites for cannabinoids [55]. Pharmacological studies have strongly suggested the existence of novel cannabinoid receptor subtypes [56, 57], and recently two orphan G-protein-coupled receptors (GPR55 and GPR119) have been proposed as cannabinoid receptors. GPR55 has been identified in the brain and peripheral tissues such as the gut, spleen, and adrenals, and, of the endocannabinoids, 2 arachidonoylglycerol (2-AG) and PEA have the greatest affinity for this receptor. GPR119 on the other hand has a narrow distribution having been described predominantly in the pancreas and intestinal tissues. The endocannabinoid with greatest affinity for GPR119 is OEA [58]. Cannabinoids can also inhibit various types of calcium channels $[59,60]$ and activate certain potassium channels [61]. In addition, the transient receptor potential vanilloid subtype 1 (TRPV1), a ligand-gated $\mathrm{Ca}^{2+}$ permeable ion channel, usually activated by stimuli such as acidity and heat and involved in the transmission and modulation of pain [62], is also activated by both AEA and acyl dopamine referred to as endovanilloids in this context [62]. Lately, the peroxisome proliferator-activated receptors (PPARs) have been included in the lists of the endocannabinoid targets, as they are stimulated by endocannabinoids under both physiological and pathological conditions [63].

\section{Endocannabinoids and Cancer}

Adjuvant cannabinoid use in the treatment of adverse side effects from chemotherapy, such as neuropathic pain, loss of appetite, nausea, and vomiting, is the most studied potential therapeutic application for these compounds [64]. Beyond the palliative effects induced by cannabinoids, these molecules and endocannabinoids are increasingly recognised for their role in the regulation of the key processes involved in the development of cancer. For example, the endocannabinoid system is reported to induce apoptosis $[11,65,66]$, cell cycle arrest [67-69], and the inhibition of angiogenesis and metastasis [70-72] in animal models and cell lines. Further research is however needed to substantiate these antineoplastic effects in humans. Furthermore, there is a suggestion that endocannabinoid signalling in the tumorigenic cell differs from that of its "normal" counterpart.

\subsection{The Endocannabinoid System: Cancer versus Normal Cell.} When considering the development of a novel anticancer treatment that "selectively targets tumour cells," thereby improving the therapeutic index of anticancer strategies, a comparison of the action of the drug in cancer cells with respect to that in normal cells represents a crucial step that must be carefully explored. Where this shows significant effects on the cancer, but not on the normal cells, such a drug will have potential benefits.

Evidence suggests that the actions of the endocannabinoid system indeed are selective in cancerous rather than in noncancerous cells [73-75]. These are affected by different components of the endocannabinoid system and result in a wide range of actions. In cancer cells such as those of the breast, melanoma, lymphoma, pancreas, and thyroid, there is increased sensitivity to endocannabinoids due to an increased level of endocannabinoid receptors in these cells compared to normal cells found in adjacent tissue obtained from the same specimen $[73,75-81]$. For example, met-fluoro-anandamide (Met-F-AEA) increases the levels of CB1 receptors in both Kras-transformed FRTL-5 (KiMol) cells and in KiMol-derived tumours in nude mice, whereas in FRTL-5 cells (a thyroiddifferentiated epithelial cell line), Met-F-AEA produced downregulation of CB1 receptors [75]. Treatment of human prostate cancer ( $\mathrm{LNCaP}$ ) cells with the $\mathrm{CB}$ agonist WIN$55,212-2$ showed significantly higher expression of both CB1 and $\mathrm{CB} 2$ receptors in these cells when compared to normal cells and interestingly a significant decrease in cell viability when treated with 1-10 $\mu \mathrm{M}$ of WIN-55,212-2 for $24-48$ hours, whilst similar doses had no effect on prostate epithelial (PrEC) cells [78].

Furthermore, the RAS-MAPK/ERK pathway in brain cells is one signalling pathway, which has been reported to be differentially regulated by cannabinoids in the cancerous cell when compared to the normal cell [82], where THC induces ceramide synthesis and glioma cell death via a CB1-mediated effect, whilst astrocytes are protected from ceramide-induced sensitisation to oxidative stress-related damage [83]. Similarly, proapoptotic and antiproliferative effects of cannabinoids on cancer cells and not on healthy tissue have been recorded in animal studies [65,76], whilst cultured oligodendroglial cells are protected from various proapoptotic stimuli [84]. Furthermore, THC induces apoptosis in several human cancer cell lines [11, 74, 85], whilst endocannabimimetic substances inhibit the proliferation of KiMol cells more robustly than FRTL-5 cells and in vivo, Met-F-AEA inhibits the growth of KiMol-induced tumours in athymic mice, an effect that was accompanied by a reduction in p21ras action [75]. In addition, ligand-induced activation of CB2 receptors reduces human breast cancer cell proliferation, whereas in normal breast tissue the expression of CB2 receptor was significantly less and the proliferation was thus much less affected [78].

Furthermore, elevated levels of AEA and 2-AG have been documented in several other cancerous tissues when compared to normal healthy counterparts, such as prostate and colon cancer, endometrial sarcoma, pituitary adenoma, and highly aggressive human cancer tissues [52, 53, 86, 87]. Recently, an increase in FAAH expression in prostate cancer cell has been reported when compared to that in the noncancerous prostate cell [88]. The expression level of MAGL is higher in androgen-independent versus androgen-dependent human prostate cancer cell lines and RNA-interference disruption of MAGL impairs prostate cancer aggressiveness [89], suggesting that 2-AG has a role to play in the aggressiveness of some types of prostate cancer.

The effect of endocannabinoids on tumorigenesis may depend on the stage of differentiation of the malignant tissues under investigation. In the human colon cancer cell line $\mathrm{Caco} 2$, endocannabinoids failed to show any proliferative effect via CB1 receptors in differentiated cells [90]; however, in undifferentiated cells, cannabinoids were strongly antiproliferative via $\mathrm{CB} 1$ and this was not because of alterations 
in the levels of $\mathrm{CB} 1$ receptors. Intriguingly, an alteration in CB1 glycosylation that probably affected cell signalling was suggested [90]. However, similar elevations in CB receptor glycosylation could not be found in human bladder, pancreas, or small intestine cancer cells $[86,91]$, suggesting this is not the main reason for the antiproliferative effects observed in the undifferentiated Caco 2 cells. The small difference in CB receptor expression, although not significant in these studies, could possibly be applicable in other hormone-dependent cancer cells.

\subsection{Endocannabinoid Receptor Signalling Actions and Conse-} quences in Cancer. The variability of endocannabinoid effects in different tumour models is highly incongruous and may be a consequence of the differential expression of cannabinoid receptors, where it is envisioned that differential expression of cannabinoid receptors between cancerous and normal tissues may play a determining role in the progression and/or inhibition of malignancy. For example, high levels of CB1 and CB2 mRNA were detected by in situ hybridization in well-differentiated human hepatocellular carcinoma and in cirrhotic liver samples, while the expression of these receptors in poorly differentiated hepatocellular carcinoma was low [92]. In addition, increased expression of CB1 and/or CB2 has been noted in human mantle cell lymphoma [80, 81], breast cancer [79], acute myeloid leukaemia [93], hepatocellular carcinoma, and prostate cancer cell lines; however, the levels of both receptors were similar in malignant and nonmalignant human astroglial cancer cells [94] and in malignant and nonmalignant nonmelanoma skin cancer cells [70].

In general, a relationship between $\mathrm{CB}$ receptor expression and the outcome of cancer has been documented. In astrocytoma cells, for example, it has been shown that $70 \%$ of cells express $\mathrm{CB} 1$ and/or $\mathrm{CB} 2$ with the extent of $\mathrm{CB} 2$ receptor expression correlating directly with the degree of tumour malignancy [66], whilst in gliomas a higher expression of CB2 receptor compared to $\mathrm{CB} 1$ receptor was found and related to tumour grade [66]. In addition, tumour-associated endothelial cells demonstrated immunoreactivity for CB1 receptors similar to that of the cancer cells [95]. Similarly, increased expression of both CB1 and CB2 receptors has been documented in non-Hodgkin lymphoma when compared to reactive lymph nodes [80], whilst CB1 expression is increased in mantle cell lymphoma [96]. In contrast, a significantly reduced expression of CB1, but not of CB2, was noted in colon cancer compared with the normal adjacent mucosa [97]. Taken together, these studies imply a role for CB1 and CB2 receptors and their expression in relation to disease prognosis and outcome and that this is greatly dependent on the type/ specific cancer being studied.

In breast carcinoma, a relationship between CB2 expression, the histological grade of the cancer, and other markers of prognostic and predictive value, such as ErbB2/HER-2 oncogene, oestrogen, and progesterone receptors, has been reported [98]. CB1 receptor expression in the human prostate cancer cell lines LNCaP (androgen-sensitive), DU145 and PC3 (androgen-insensitive) has been reported to be higher than in the normal human prostate epithelial cells [78]. This was confirmed in prostate cancer tissues where the expressions of CB1 and TRPV1 receptors were upregulated and furthermore correlated with increasing cancer grade [99]. Moreover, the level of CB1 receptor expression in cancer specimens has been shown to correlate with the disease severity at diagnosis and outcome [100]. In human pancreatic cancer, higher levels of CB1 receptor expression are related to a shorter survival time (median 6 months) than lower CB1 receptor (median 16 months) [91]. In contrast, the overexpression of CB1 and $\mathrm{CB} 2$ receptors found in human hepatocellular carcinoma was associated with improved prognosis [92].

The mechanism by which endocannabinoid receptor expression is modulated in relation to cancer has not been fully examined; however, several studies have revealed important evidence for further relationships between cannabinoid receptors and cancer, where transcription factor involvement has been postulated. Indeed, it has been shown that THC induces a CB2-receptor-dependent transcription of the CB1 gene in human $\mathrm{T}$ cells and $\mathrm{T}$ cell lymphoma lines, mediated via IL-4 release through activation of the transcription factor STAT6 [101]. In addition, expression of CB2 is induced following the oral administration of specific Lactobacillus strains in colonic epithelial cells, through the NF- $\kappa$ B pathway [102], whilst it has been reported that $\mathrm{CB} 1$ receptor expression in human colon cancer was induced by $17 \beta$-oestradiol through an oestrogen-receptor-dependent mechanism [103]. In alveolar rhabdomyosarcoma, $\mathrm{CB1}$ receptor expression has greatly increased and this was evident in chromatin immunoprecipitation studies, which have demonstrated that the CB1 gene is a transcriptional target of PAX3/FKHR, a chimeric transcription factor found in this condition [104]. Another hypothesis, that has been examined, is that alternatively spliced isoforms of CB1 (CB1a and CB1b), which could reflect differences in its functionality in normal and cancerous tissues, are responsible for the variability in the response described above [105].

\subsection{The Endocannabinoid System and Sex Steroid Hormones.} The endocannabinoid system is widespread throughout the central nervous system (CNS) and peripheral regions and regulates a large range of physiological functions and behaviour. The same can also be said of the sex steroid hormones. As stated above, there is evidence suggesting that the two systems interact extensively (Figure 5).

2.3.1. The Role of Progesterone. Progesterone is a C-21 steroid hormone that is produced predominantly by the ovarian corpus luteum after ovulation and is possibly involved in the regulation of endocannabinoid signalling. Progesterone has been shown to upregulate human lymphocyte FAAH activity through the transcription factor Ikaros $[106,107]$ and thereby decreases plasma AEA levels [108]. Whether this is a general phenomenon or a $\mathrm{T}$ cell specific effect needs clarification since the expression of Ikaros transcription factors seems to be confined to the T cell [109]. Furthermore, while progesterone increases FAAH expression and its activity in immortalized human lymphoma U937 cells, but not in immortalized human neuroblastoma CPH100 cells [110], it has been 


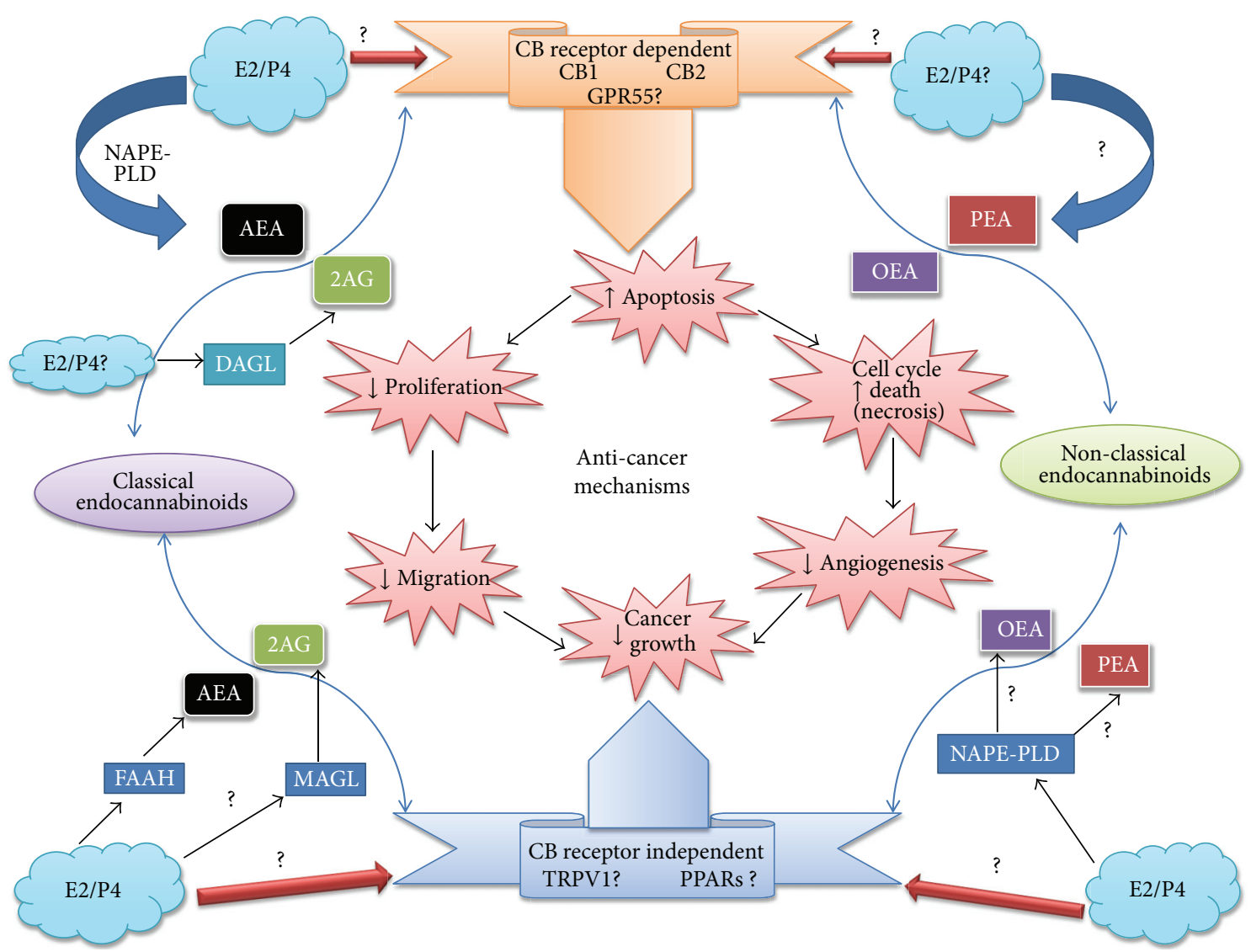

Figure 5: Known and putative interactions between gonadal sex steroids and the endocannabinoid system in sex hormone-dependent cancers. Endocannabinoid synthesis occurs through the actions of specific enzymes (blue boxes and broad arrows) through enzymatic hydrolysis of membrane specific NArPE lipid precursors. The role of the sex steroid hormones oestradiol (E2) and progesterone (P4) (blue clouds) is only speculative. The classical (anandamide (AEA) and 2-arachidonoylglycerol (2-AG)) and nonclassical endocannabinoids ( $N$ oleoylethanolamine (OEA) and N-palmitoylethanolamine (PEA)) independently or collectively bind at both classical (CB1, CB2, and GPR55) and nonclassical (TRPV1 and PPAR) receptors (ribbons) to affect anticancer mechanisms (pink starbursts in the centre of the figure), which may be linked (arrows) or may not be linked to each other, but all result in reduced cancer cell mass. Known interactions between sex steroid hormones and the endocannabinoid system in the anticancer mechanisms are shown, whereas speculative or unknown interactions are indicated by the presence of a question mark. Up and down arrows indicate either an increase or decrease in the activity of that particular anticancer mechanism.

reported to have a minimal effect on EMT, NAPE-PLD, and CB1 expression in lymphocytes [106, 107]. Progesterone has also been documented to downregulate uterine NAPE-PLD expression in mice, leading to a decrease in tissue AEA levels [111]. In the pregnant mouse uterus, it has also been reported to downregulate FAAH activity [112], and when taken together with reduced NAPE-PLD expression in mice these data suggest that the NAPE-PLD : FAAH activity ratio in the mouse uterus may be key to the regulation of local AEA levels and thus maintenance of pregnancy or endometrial pathologies, such as cancer. At the same time, the actions of progesterone on local AEA levels in the rat uterus are more complex with progesterone stimulating its production in the ovariectomised animal [113]. These authors concluded that "...the effect of ovarian hormones on the synthesis of anandamide depends on different physiological conditions, (including the) oestrous cycle and early pregnancy, and on the presence of the activated blastocyst..., but the precise feedback mechanisms that might be involved are unknown. For example, treatment with either $\mathrm{CB} 1$ or $\mathrm{CB} 2$ receptor agonists reduces the levels of serum progesterone, corpus luteum weights, corpus luteum LH receptor mRNA content, and corpus luteum LH receptor density in sheep [114]. It has also been reported that the levels of serum progesterone and LH content are decreased following chronic administration of AEA in pregnant rats [115], suggesting that both positive and negative feedback loops are involved in the coregulation of endocannabinoid and progesterone function.

2.3.2. The Role of Oestrogen. Oestrogens are also steroid hormones, produced predominantly by the ovarian follicle during the early stage of the menstrual and oestrous cycles. Once inside the cell, oestrogens bind to and activate specific oestrogen receptors, resulting in the regulation of the expression of multiple gene targets involved in cellular proliferation, apoptosis, and autophagy [116]. Although FSH and LH stimulate the synthesis of oestrogen in the ovaries, there are other nonovarian sources of oestrogens such as the breast, 
the adrenal glands, and the liver, but the levels produced are relatively small and probably only have local actions [117]. The most potent growth stimulating oestrogen is $17 \beta$-oestradiol (E2), which has been linked directly and indirectly with the endocannabinoid system, where E2 stimulates NAPEPLD and inhibits FAAH synthesis and directly stimulates the release of AEA from endothelial cells [108, 118, 119]. By contrast, another study revealed that NAPE-PLD is downregulated in the uterus by oestradiol, suggesting that it results in decreased anandamide levels, although this was not directly tested [111]. However, other studies revealed that E2 decreases the activity of FAAH in the mouse uterus [108, 118], whilst also regulating the expression of FAAH [112]. Moreover, in cancers, such as glioma, breast, and colon, oestrogens appear to regulate the ECS [120]. Evidence of cannabinoid and oestrogen receptor coexpression has been documented in colorectal carcinoma and normal colonic epithelium [90] and in the human anterior pituitary gland [121], where E2 regulates CB1 mRNA expression, a feature it also shared within the rat hypothalamus [121]. These differential effects of oestrogens on components of endocannabinoid signalling pathways reveal an intricate interaction which may play an important role in sex steroid hormone-dependent tumours.

\section{The ECS and Breast Cancer}

Breast cancer is the most common cancer in women [122]. It is dependent on hormones, such as oestrogen and progesterone, for initial growth and survival. Risk factors for the development of breast cancer include lower fertility, nonbreastfeeding, genetic predisposition, higher hormone levels, and iodine deficiency [123]. Bones, lungs, and lymph node are among the sites where breast cancer cell may spread [124, 125], but the cancer itself normally develops from breast tissues surrounding the milk ducts (ductal neoplasm) or breast lobules (lobular neoplasm) [126]. Cannabinoid receptors have been documented to be present in breast tissue; CB1 immunoreactivity was expressed in $28 \%$ of human breast cancer samples [127] and immunohistochemistry studies have revealed the presence of CB1 in 14\% of human breast cancer tissues expressing ErbB2, which is a member of the epidermal growth factor (EGF), but interestingly with no relationship between $\mathrm{CB} 1$ and ErbB2 expression [128]. CB1 receptors have also been documented in human breast tissues using Western blot, immunofluorescence, and/or RT-PCR techniques as well as in various breast cancer cell lines (T-47D, MCF-7, MDA-MB-231, TSA-E1, and MDA-MB-468) [69, 103, 127, 129, 130].

In contrast, CB2 immunoreactivity was documented in $72 \%$ of human breast tissues [128], and is present in $91 \%$ of ErbB2-positive cancer tissues (in contrast to CB1 receptor), suggesting a relationship between $\mathrm{CB} 1$ receptor and the ErbB2-positive cancer cell phenotype [128]. CB2 immunoreactivity was noted in 35\% of human breast cancer tissues [127] while $\mathrm{CB} 2$ receptors were expressed in a variety of breast cancer cell lines (T-47D, MCF-7, MDA-MB-231, MDA-MD468, EVSA-T, and $\mathrm{SkBr} 3$ ) and human breast tissues as determined by Western blot, RT-PCR, and/or immunofluorescence techniques $[69,103,127,129,130]$. In addition, FAAH transcripts are present in the EFM-19 and MCF-7 cancer cell lines, as determined by northern blotting [131] and RT-PCR [132] techniques, whilst GPR55 is highly expressed in the MDA-MB-231 and MCF-7 breast cancer cell lines [133].

Recent research has identified a role for the endocannabinoid system in the regulation of breast cancer growth, with induction of apoptosis and control of cancer neovascularization in breast cancer being key control points [127, 128, $130,134]$ and importantly a critical relationship with oestrogen [116]. These effects are achieved through a variety of mechanisms; for example, CBD seems to involve direct TRPV1 activation and/or CB2 indirect activation (via FAAH), induction of oxidative stress [130], and the ability to decrease ID-1, an inhibitor of basic helix-loop-helix transcription factor. The expression of ID-1 in breast cancer cells was associated with its efficacy in reducing proliferation, migration, and invasion [135]. In these types of cell lines, the endocannabinoid system induces growth arrest by downregulating prolactin receptor expression [67]. Therefore, breast cancer proliferation depends on signalling via the $\mathrm{CB} 1$ receptor, which has been revealed to downregulate the prolactin receptor and indirectly inhibit cell growth [67]. Furthermore, these effects were also noted when FAAH activity was blocked [67], suggesting that AEA is somehow involved in this process. In addition, the antiproliferative effects of the endocannabinoid system were shown to be mediated through downregulation of the high affinity NGF receptor [69]. Similarly, the ECS inhibits breast cancer growth in vivo, by acting through the $\mathrm{CB} 1$ receptor [134]. Finally, a recent study showed that CBD induces a concentration-dependent cell death of both oestrogen receptor-positive and oestrogen receptor-negative breast cancer cells through a mechanism involving a CB1-, CB2-, and TRPV1-independent receptor activation [116]. Furthermore, the gender-specific actions of E2 in the hippocampus, where the ER $\alpha$-specific inhibition of CB1-dependent signalling in a subset of neurons occurs only in female and not in male mice, whilst $\mathrm{ER} \beta$-specific stimulation occurs in both genders, suggest that there may be a complex interaction between oestrogen and cannabinoid signalling, at least in the rat hippocampus [136]. Considering that the E2-activated $\mathrm{ER} \alpha$ promotes human breast cancer cell growth [137] and the E2-activated $\mathrm{ER} \beta$ receptor inhibits human endometrial cancer cell growth [138] and that cannabinoids may affect both breast and endometrial cancer growth and development, then a potential interaction between these two signalling pathways seems plausible and should be investigated further.

\section{The ECS and Prostate Cancer}

Prostate carcinoma is the second most common cancer diagnosed in men [122]. Factors such as diet, genetic predisposition, medical exposure to hormones, and viral infections are all implicated in the incidence of prostate cancer [139]. The majority of prostate cancers have a slow progression, although cases of aggressive prostate cancer do occur. Common sites of prostate metastasis are particularly in the bones and lymph nodes $[139,140]$. CB1 expression is upregulated 
in prostate cancer tissues [99] and the levels of the receptor are associated with cancer severity and outcome [100]. In addition, RT-PCR, Western blot, and immunofluorescence studies have shown that prostate cancer cell lines, PC-3, DU-145, LNCaP, CWR22Rv1, and CA-HPV-10, and human prostate tumour tissues express CB1 $[69,78,87,99,100,141$, $142]$. CB2 receptors are also present in the same prostate cancer cell lines $[69,78,87,142]$ and these cancer cell lines express higher levels of CB1 and CB2 than benign prostate epithelium [78]. In addition, FAAH expression has been demonstrated in the prostate cancer cell lines (PC-3, DU-145, and LNCaP) and human prostate cancer tissues [88, 97, 125, 142, 143]. GPR55 is also expressed in the PC-3 and DU-145 prostate cancer cell lines [144]. Thus, various cannabinoid receptor subtypes and endocannabinoid hydrolysing enzymes are known to be located in prostate tissue and synthetic cannabinoids, endocannabinoids, and related compounds appear to inhibit prostate tumour cell proliferation and induce apoptosis via $\mathrm{CB} 1$ and/or CB2 receptor activation.

Prolactin (PRL) is necessary for the prostate to be completely formed. Prolactin is a hormone produced by the anterior pituitary gland in lactotroph cells and its gene is located on chromosome 6 [145]. Prolactin plays a vital role in prostate cell proliferation, differentiation, and survival, in normal as well as in malignant cells [146]. This has led to the suggestion that prostate cancer may express prolactin receptors and proliferate in response to prolactin levels and this response can be inhibited by cannabinoids. When induced by exogenous PRL, the proliferation of prostate DU-145 cells was potently inhibited (IC50 $=100-300 \mathrm{nM}$ ) by anandamide, 2AG, and HU-210. Anandamide was also noted to downregulate the levels of prolactin in DU-145 cells [69].

Several intraepithelial or invasive prostate cancers have exhibited increased expression of epidermal growth factor receptor (EGF-R), tyrosine kinase, and EGF. The EGFR levels can be downregulated by micromolar concentrations of AEA via the CB1 receptor and this results in the inhibition of proliferation at day 3 and cell death by apoptosis/necrosis on day 5, with this effect being manifest through both CB1 and CB2 receptors [147]. Cannabinoids have also been documented to downregulate androgen receptor expression and prostate specific antigen (PSA) [148]; however, the sensitivity to cannabinoids seems to be inconsistent in different prostate cancer cell lines, even in the presence of CB receptors $[128,147,148]$.

\section{The ECS and Endometrial Cancer}

Worldwide, endometrial cancer is the seventh most commonly diagnosed malignancy [149] and the 4th most common gynaecological cancer diagnosed in 2008 in the UK [150]. Endometrial cancer refers to several types of malignancies that arise from the endometrium, and early menarche, late menopause, obesity, nulliparity, and the use of oestrogenonly hormone replacement therapy have all been identified as risk factors for the development of endometrial carcinoma, which suggest that greater lifetime exposure to oestrogen, unopposed by progesterone, plays a vital role in the aetiology of endometrial cancer $[151,152]$. Exposure to endogenous or exogenous oestrogens and the use of unopposed progesterone lead to an increase in the mitotic activity of endometrial epithelial cells and increased DNA replication and repair errors, which in turn leads to various somatic mutations that may ultimately result in endometrial hyperplasia, which may finally result in the development of malignancy $[153,154]$. Chronic inflammation has also been implicated as a vital player in the relationship between obesity, menstrual disorders, and endometrial cancer [153]. Moreover, conditions such as uterine fibroids and endometriosis may produce an increased risk of endometrial cancer because these disorders have been linked to both pelvic inflammation [155-157] and an excess of oestrogen $[158,159]$. Based on clinicopathological and molecular characteristics, there are two types of endometrial cancers. The first is the type I or oestrogen-dependent endometrioid carcinomas (EECs), which constitute approximately $80 \%$ of the cases of endometrial carcinoma. These tumours express oestrogen (ER) and progesterone (PR) receptors and arise in younger pre- and postmenopausal women [160]. Type I is also strongly associated with either endogenous or exogenous unopposed oestrogen exposure and is usually of low grade and characterised by a favourable prognosis. The second group, the type II or nonendometrioid endometrial carcinomas (NEECs), are comprised of the high grade papillary serous and clear cell carcinomas [161]. These arise in relatively older women and are not usually preceded by an unopposed oestrogen exposure history but have an aggressive clinical course and a worse prognosis than type I cancers [161].

The expression of endocannabinoid receptors in different endometrial cancer tissues/cell lines has been described, where CB2 expression was detected by immunohistochemistry only in the endometrial cancer cells and not in the normal endometrial tissue taken from the same biopsy [162]. Immunoblotting analysis showed that CB2 protein expression was significantly elevated in the endometrial cancer tissues when compared to healthy endometrial tissues [162] and no significant differences were noted in CB1 expression [162]. A mass spectrometry study showed selective upregulation of 2-AG in endometrial cancer tissues compared to healthy endometrial tissues, whilst no significant increases in the levels of AEA or PEA were noted [162]. Similarly, immunoblotting revealed a selective downregulation of MAGL expression in endometrial cancer tissues compared with healthy tissue and, interestingly, there were no significant differences in FAAH protein expression [162]. Furthermore, evidence suggests that $\mathrm{CB} 2$ receptor regulation is dysregulated in endometrial cancer, because CB2 levels were significantly higher in the AN3CA human endometrial carcinoma cell line compared to control cells when transfected with a plasmid containing the cDNA for the endocannabinoid receptor CB2 [162]. From these data, it has been concluded that CB2 receptors might play a vital role in the growth of endometrial cancer [163].

Recent research has shown that the complete endogenous pathway for CB2 was altered significantly in endometrial adenocarcinoma, which may thus be one of the underlying factors for endocannabinoid system regulation in the aetiology of endometrial cancer. The marked elevation in CB2 
receptor expression and 2-AG in endometrial cancer tissues might be due to the underlying imbalance in the oestrogen/ progesterone ratio, which is one of the aetiological factors for the development of endometrial cancer [162], but this has not been fully tested. What has been tested was the effect of CB2 elevation in transfected AN3CA cells where CB2 caused a $40 \%$ reduction of cell mitochondrial function when compared to the control cells [163]. This effect was not improved by the CB2 receptor agonist, JWH133, but was fully prevented by the CB2 receptor antagonist SR144528.

The specific increased expression of CB2 receptors in only the tumour developing cells might represent a novel indicator for the diagnosis of endometrial cancer. Therefore, selective CB2 agonists might represent the foundation for the development of new antitumour compounds against endometrial carcinoma, because they have the ability to kill the affected cancer cells without damaging their normal counterparts [164].

\section{Conclusions and Future Directions}

Currently available studies suggest that the endocannabinoid system may be targeted to restrain the development and progression of breast, prostate, and endometrial carcinoma. The endocannabinoid system exerts a variety of interesting effects that are dependent on the cell line and/or tumour type under investigation, where the ECS, for example, inhibits cancer cell proliferation, angiogenesis, cancer growth, metastasis, and apoptosis. The prevailing data suggest that an imbalance in the endocannabinoid system and its interaction with sex steroid hormone homeostasis may promote cancer development, proliferation, and migration. Therefore, for this vital reason, and although it is early days, the endocannabinoid system has become an attractive novel target for pharmacological intervention in the fight against many hormonerelated cancers.

\section{References}

[1] N. M. Kogan and R. Mechoulam, "Cannabinoids in health and disease," Dialogues in Clinical Neuroscience, vol. 9, no. 4, pp. 413430, 2007.

[2] J. Guindon and A. G. Hohmann, "The endocannabinoid system and cancer: therapeutic implication," British Journal of Pharmacology, vol. 163, no. 7, pp. 1447-1463, 2011.

[3] D. Cota and S. C. Woods, "The role of the endocannabinoid system in the regulation of energy homeostasis," Current Opinion in Endocrinology \& Diabetes, vol. 12, no. 5, pp. 338-351, 2005.

[4] L. de Petrocellis, M. G. Cascio, and V. di Marzo, “The endocannabinoid system: a general view and latest additions," British Journal of Pharmacology, vol. 141, no. 5, pp. 765-774, 2004.

[5] L. A. Matsuda, S. J. Lolait, M. J. Brownstein, A. C. Young, and T. I. Bonner, "Structure of a cannabinoid receptor and functional expression of the cloned cDNA," Nature, vol. 346, no. 6284, pp. 561-564, 1990.

[6] C. Ledent, O. Valverde, G. Cossu et al., "Unresponsiveness to cannabinoids and reduced addictive effects of opiates in $\mathrm{CB}_{1}$ receptor knockout mice," Science, vol. 283, no. 5400, pp. 401404, 1999.
[7] A. Zimmer, A. M. Zimmer, A. G. Hohmann, M. Herkenham, and T. I. Bonner, "Increased mortality, hypoactivity, and hypoalgesia in cannabinoid $\mathrm{CB}_{1}$ receptor knockout mice," Proceedings of the National Academy of Sciences of the United States of America, vol. 96, no. 10, pp. 5780-5785, 1999.

[8] S. Munro, K. L. Thomas, and M. Abu-Shaar, "Molecular characterization of a peripheral receptor for cannabinoids," Nature, vol. 365, no. 6441, pp. 61-65, 1993.

[9] N. E. Buckley, K. L. McCoy, É. Mezey et al., "Immunomodulation by cannabinoids is absent in mice deficient for the cannabinoid $\mathrm{CB}_{2}$ receptor," European Journal of Pharmacology, vol. 396, no. 2-3, pp. 141-149, 2000.

[10] M. Bifulco and V. di Marzo, "Targeting the endocannabinoid system in cancer therapy: a call for further research," Nature Medicine, vol. 8, no. 6, pp. 547-550, 2002.

[11] I. Galve-Roperh, C. Sánchez, M. L. Cortés, T. G. del Pulgar, M. Izquierdo, and M. Guzmán, "Anti-tumoral action of cannabinoids: involvement of sustained ceramide accumulation and extracellular signal-regulated kinase activation," Nature Medicine, vol. 6, no. 3, pp. 313-319, 2000.

[12] F. Cianchi, L. Papucci, N. Schiavone et al., "Cannabinoid receptor activation induces apoptosis through tumor necrosis factor $\alpha$-mediated ceramide de novo synthesis in colon cancer cells," Clinical Cancer Research, vol. 14, no. 23, pp. 7691-7700, 2008.

[13] D. Piomelli, A. Giuffrida, A. Calignano, and F. Rodríguez De Fonseca, "The endocannabinoid system as a target for therapeutic drugs," Trends in Pharmacological Sciences, vol. 21, no. 6, pp. 218-224, 2000.

[14] M. Maccarrone, M. van der Stelt, A. Rossi, G. A. Veldink, J. F. G. Vliegenthart, and A. F. Agrò, "Anandamide hydrolysis by human cells in culture and brain," Journal of Biological Chemistry, vol. 273, no. 48, pp. 32332-32339, 1999.

[15] W. A. Devane, L. Hanus, A. Breuer et al., "Isolation and structure of a brain constituent that binds to the cannabinoid receptor," Science, vol. 258, no. 5090, pp. 1946-1949, 1992.

[16] R. Mechoulam, S. Ben-Shabat, L. Hanuš et al., "Identification of an endogenous 2-monoglyceride, present in canine gut, that binds to cannabinoid receptors," Biochemical Pharmacology, vol. 50, no. 1, pp. 83-90, 1995.

[17] R. G. Pertwee, "Pharmacological actions of cannabinoids," Handbook of Experimental Pharmacology, no. 168, pp. 1-51, 2005.

[18] D. Piomelli, "The molecular logic of endocannabinoid signalling," Nature Reviews Neuroscience, vol. 4, no. 11, pp. 873-884, 2003.

[19] I. Matias and V. di Marzo, "Endocannabinoid synthesis and degradation, and their regulation in the framework of energy balance," Journal of Endocrinological Investigation, vol. 29, supplement 3, pp. 15-26, 2006.

[20] V. di Marzo, A. Fontana, H. Cadas et al., "Formation and inactivation of endogenous cannabinoid anandanide in central neurons," Nature, vol. 372, no. 6507, pp. 686-691, 1994.

[21] Y. Okamoto, J. Morishita, K. Tsuboi, T. Tonai, and N. Ueda, "Molecular characterization of a phospholipase D generating anandamide and its congeners," Journal of Biological Chemistry, vol. 279, no. 7, pp. 5298-5305, 2004.

[22] S. M. Prescott and P. W. Majerus, "Characterization of 1,2-diacylglycerol hydrolysis in human platelets. Demonstration of an arachidonoyl-monoacylglycerol intermediate," Journal of Biological Chemistry, vol. 258, no. 2, pp. 764-769, 1983.

[23] M. J. McFarland and E. L. Barker, "Anandamide transport," Pharmacology \& Therapeutics, vol. 104, no. 2, pp. 117-135, 2004. 
[24] B. F. Cravatt, D. K. Giang, S. P. Mayfield, D. L. Boger, R. A. Lerner, and N. B. Gilula, "Molecular characterization of an enzyme that degrades neuromodulatory fatty-acid amides," Nature, vol. 384, no. 6604, pp. 83-87, 1996.

[25] V. di Marzo, T. Bisogno, T. Sugiura, D. Melck, and L. de Petrocellis, "The novel endogenous cannabinoid 2-arachidonoylglycerol is inactivated by neuronal- and basophil-like cells: connections with anandamide," Biochemical Journal, vol. 331, part 1, pp. 1519, 1998

[26] S. K. Goparaju, N. Ueda, K. Taniguchi, and S. Yamamoto, "Enzymes of porcine brain hydrolyzing 2-arachidonoylglycerol, an endogenous ligand of cannabinoid receptors," Biochemical Pharmacology, vol. 57, no. 4, pp. 417-423, 1999.

[27] J. Fu, G. Bottegoni, O. Sasso et al., "A catalytically silent FAAH-1 variant drives anandamide transport in neurons," Nature Neuroscience, vol. 15, no. 1, pp. 64-69, 2012.

[28] T. Bisogno, D. Melck, M. Y. Bobrov et al., "N-acyl-dopamines: novel synthetic $\mathrm{CB}_{1}$ cannabinoid-receptor ligands and inhibitors of anandamide inactivation with cannabimimetic activity in vitro and in vivo," Biochemical Journal, vol. 351, part 3, pp. 817-824, 2000.

[29] A. C. Porter, J.-M. Sauer, M. D. Knierman et al., "Characterization of a novel endocannabinoid, virodhamine, with antagonist activity at the $\mathrm{CB}_{1}$ receptor," Journal of Pharmacology and Experimental Therapeutics, vol. 301, no. 3, pp. 1020-1024, 2002.

[30] V. di Marzo, “Endocannabinoids' and other fatty acid derivatives with cannabimimetic properties: biochemistry and possible physiopathological relevance," Biochimica et Biophysica Acta, vol. 1392, no. 2-3, pp. 153-175, 1998.

[31] M. Maccarrone and A. Finazzi-Agró, "Endocannabinoids and their actions," Vitamins and Hormones, vol. 65, pp. 225-255, 2002.

[32] K. Katayama, N. Ueda, Y. Kurahashi, H. Suzuki, S. Yamamoto, and I. Kato, "Distribution of anandamide amidohydrolase in rat tissues with special reference to small intestine," Biochimica et Biophysica Acta, vol. 1347, no. 2-3, pp. 212-218, 1997.

[33] S. Ben-Shabat, E. Fride, T. Sheskin et al., "An entourage effect: inactive endogenous fatty acid glycerol esters enhance 2-arachidonoyl-glycerol cannabinoid activity," European Journal of Pharmacology, vol. 353, no. 1, pp. 23-31, 1998.

[34] L. M. Bornheim, K. Y. Kim, B. Chen, and M. A. Correia, "Microsomal cytochrome P450-medited liver and brain anandamide metabolism," Biochemical Pharmacology, vol. 50, no. 5, pp. 677686, 1995.

[35] L. M. Bornheim, E. T. Everhart, J. Li, and M. A. Correia, "Characterization of cannabidiol-mediated cytochrome P450 inactivation," Biochemical Pharmacology, vol. 45, no. 6, pp. 1323-1331, 1993.

[36] W. S. Edgemond, C. J. Hillard, J. R. Falck, C. S. Kearn, and W. B. Campbell, "Human platelets and polymorphonuclear leukocytes synthesize oxygenated derivatives of arachidonylethanolamide (anandamide): their affinities for cannabinoid receptors and pathways of inactivation," Molecular Pharmacology, vol. 54, no. 1, pp. 180-188, 1998.

[37] K. R. Kozak and L. J. Marnett, "Oxidative metabolism of endocannabinoids," Prostaglandins Leukotrienes and Essential Fatty Acids, vol. 66, no. 2-3, pp. 211-220, 2002.

[38] M. Yu, D. Ives, and C. S. Ramesha, "Synthesis of prostaglandin E2 ethanolamide from anandamide by cyclooxygenase-2," Journal of Biological Chemistry, vol. 272, no. 34, pp. 21181-21186, 1997.

[39] K. R. Kozak, S. W. Rowlinson, and L. J. Marnett, "Oxygenation of the endocannabinoid, 2-arachidonylglycerol, to glyceryl prostaglandins by cyclooxygenase-2," Journal of Biological Chemistry, vol. 275, no. 43, pp. 33744-33749, 2000.

[40] K. R. Kozak, B. C. Crews, J. L. Ray, H.-H. Tai, J. D. Morrow, and L. J. Marnett, "Metabolism of prostaglandin glycerol esters and prostaglandin ethanolamides in vitro and in vivo," Journal of Biological Chemistry, vol. 276, no. 40, pp. 36993-36998, 2001.

[41] G. Fürstenberger, P. Krieg, K. Müller-Decker, and A. J. R. Habenicht, "What are cyclooxygenases and lipoxygenases doing in the driver's seat of carcinogenesis?" International Journal of Cancer, vol. 119, no. 10, pp. 2247-2254, 2006.

[42] J. Wang and N. Ueda, "Role of the endocannabinoid system in metabolic control," Current Opinion in Nephrology and Hypertension, vol. 17, no. 1, pp. 1-10, 2008.

[43] P. Mailleux, M. Parmentier, and J.-J. Vanderhaeghen, "Distribution of cannabinoid receptor messenger RNA in the human brain: an in situ hybridization histochemistry with oligonucleotides," Neuroscience Letters, vol. 143, no. 1-2, pp. 200-204, 1992.

[44] M. Glass, M. Dragunow, and R. L. M. Faull, "Cannabinoid receptors in the human brain: a detailed anatomical and quantitative autoradiographic study in the fetal, neonatal and adult human brain," Neuroscience, vol. 77, no. 2, pp. 299-318, 1997.

[45] J.-P. Gong, E. S. Onaivi, H. Ishiguro et al., "Cannabinoid $\mathrm{CB}_{2}$ receptors: immunohistochemical localization in rat brain," Brain Research, vol. 1071, no. 1, pp. 10-23, 2006.

[46] P. Pacher, S. Bátkai, and G. Kunos, “The endocannabinoid system as an emerging target of pharmacotherapy," Pharmacological Reviews, vol. 58, no. 3, pp. 389-462, 2006.

[47] B. S. Basavarajappa, "Neuropharmacology of the endocannabinoid signaling system-molecular mechanisms, biological actions and synaptic plasticity," Current Neuropharmacology, vol. 5, no. 2, pp. 81-97, 2007.

[48] C. M. Gerard, C. Mollereau, G. Vassart, and M. Parmentier, "Molecular cloning of a human cannabinoid receptor which is also expressed in testis," Biochemical Journal, vol. 279, part 1, pp. 129-134, 1991.

[49] M. Bouaboula, M. Rinaldi, P. Carayon et al., "Cannabinoidreceptor expression in human leukocytes," European Journal of Biochemistry, vol. 214, no. 1, pp. 173-180, 1993.

[50] J. Liu, B. Gao, F. Mirshahi et al., "Functional $\mathrm{CB}_{1}$ cannabinoid receptors in human vascular endothelial cells," Biochemical Journal, vol. 346, part 3, pp. 835-840, 2000.

[51] A. Porcella, C. Maxia, G. L. Gessa, and L. Pani, “The human eye expresses high levels of $\mathrm{CB}_{1}$ cannabinoid receptor mRNA and protein," The European Journal of Neuroscience, vol. 12, no. 3, pp. 1123-1127, 2000.

[52] U. Pagotto, G. Marsicano, F. Fezza et al., "Normal human pituitary gland and pituitary adenomas express cannabinoid receptor type 1 and synthesize endogenous cannabinoids: first evidence for a direct role of cannabinoids on hormone modulation at the human pituitary level," Journal of Clinical Endocrinology and Metabolism, vol. 86, no. 6, pp. 2687-2696, 2001.

[53] M. Bifulco, C. Laezza, S. Pisanti, and P. Gazzerro, "Cannabinoids and cancer: pros and cons of an antitumour strategy," British Journal of Pharmacology, vol. 148, no. 2, pp. 123-135, 2006.

[54] M. R. El-Talatini, A. H. Taylor, J. C. Elson, L. Brown, A. C. Davidson, and J. C. Konje, "Localisation and function of the endocannabinoid system in the human ovary," PLOS ONE, vol. 4, no. 2, Article ID e4579, 2009.

[55] B. Lutz, "Molecular biology of cannabinoid receptors," Prostaglandins Leukotrienes and Essential Fatty Acids, vol. 66, no. 2-3, pp. 123-142, 2002. 
[56] M. Begg, P. Pacher, S. Bátkai et al., "Evidence for novel cannabinoid receptors," Pharmacology \& Therapeutics, vol. 106, no. 2, pp. 133-145, 2005.

[57] K. Mackie and N. Stella, "Cannabinoid receptors and endocannabinoids: evidence for new players," The AAPS Journal, vol. 8, no. 2, article 34, pp. E298-E306, 2006.

[58] G. Godlewski, L. Offertáler, J. A. Wagner, and G. Kunos, "Receptors for acylethanolamides-GPR55 and GPR119," Prostaglandins \& Other Lipid Mediators, vol. 89, no. 3-4, pp. 105-111, 2009.

[59] K. Mackie and B. Hille, "Cannabinoids inhibit N-type calcium channels in neuroblastoma-glioma cells," Proceedings of the National Academy of Sciences of the United States of America, vol. 89, no. 9, pp. 3825-3829, 1992.

[60] D. Gebremedhin, A. R. Lange, W. B. Campbell, C. J. Hillard, and D. R. Harder, "Cannabinoid $\mathrm{CB}_{1}$ receptor of cat cerebral arterial muscle functions to inhibit L-type $\mathrm{Ca}^{2+}$ channel current," American Journal of Physiology: Heart and Circulatory Physiology, vol. 276, no. 6, part 2, pp. H2085-H2093, 1999.

[61] K. Mackie, Y. Lai, R. Westenbroek, and R. Mitchell, "Cannabinoids activate an inwardly rectifying potassium conductance and inhibit Q-type calcium currents in AtT20 cells transfected with rat brain cannabinoid receptor," Journal of Neuroscience, vol. 15, no. 10, pp. 6552-6561, 1995.

[62] S. M. Huang, T. Bisogno, M. Trevisani et al., "An endogenous capsaicin-like substance with high potency at recombinant and native vanilloid VR1 receptors," Proceedings of the National Academy of Sciences of the United States of America, vol. 99, no. 12, pp. 8400-8405, 2002.

[63] M. Pistis and M. Melis, "From surface to nuclear receptors: the endocannabinoid family extends its assets," Current Medicinal Chemistry, vol. 17, no. 14, pp. 1450-1467, 2010.

[64] W. Hall, M. Christie, and D. Currow, "Cannabinoids and cancer: causation, remediation, and palliation," The Lancet Oncology, vol. 6, no. 1, pp. 35-42, 2005.

[65] T. G. del Pulgar, G. Velasco, C. Sánchez, A. Haro, and M. Guzmán, "De novo-synthesized ceramide is involved in cannabinoid-induced apoptosis," Biochemical Journal, vol. 363, part 1, pp. 183-188, 2002.

[66] C. Sánchez, M. L. de Ceballos, T. Gómez del Pulgar et al., "Inhibition of glioma growth in vivo by selective activation of the $\mathrm{CB}_{2}$ cannabinoid receptor," Cancer Research, vol. 61, no. 15, pp. 57845789, 2001.

[67] L. de Petrocellis, D. Melck, A. Palmisano et al., “The endogenous cannabinoid anandamide inhibits human breast cancer cell proliferation," Proceedings of the National Academy of Sciences of the United States of America, vol. 95, no. 14, pp. 8375-8380, 1998.

[68] D. Melck, D. Rueda, I. Galve-Roperh, L. de Petrocellis, M. Guzmán, and V. di Marzo, "Involvement of the cAMP/protein kinase A pathway and of mitogen- activated protein kinase in the anti-proliferative effects of anandamide in human breast cancer cells," FEBS Letters, vol. 463, no. 3, pp. 235-240, 1999.

[69] D. Melck, L. de Petrocellis, P. Orlando et al., "Suppression of nerve growth factor Trk receptors and prolactin receptors by endocannabinoids leads to inhibition of human breast and prostate cancer cell proliferation," Endocrinology, vol. 141, no. 1, pp. 118-126, 2000.

[70] M. Llanos Casanova, C. Blázquez, J. Martínez-Palacio et al., "Inhibition of skin tumor growth and angiogenesis in vivo by activation of cannabinoid receptors," Journal of Clinical Investigation, vol. 111, no. 1, pp. 43-50, 2003.
[71] C. Blázquez, M. L. Casanova, A. Planas et al., "Inhibition of tumor angiogenesis by cannabinoids," FASEB Journal, vol. 17, no. 3, pp. 529-531, 2003.

[72] G. Portella, C. Laezza, P. Laccetti, L. de Petrocellis, V. di Marzo, and M. Bifulco, "Inhibitory effects of cannabinoid $\mathrm{CB}_{1}$ receptor stimulation on tumor growth and metastatic spreading: actions on signals involved in angiogenesis and metastasis," FASEB Journal, vol. 17, no. 12, pp. 1771-1773, 2003.

[73] C. Blázquez, A. Carracedo, L. Barrado et al., "Cannabinoid receptors as novel targets for the treatment of melanoma," FASEB Journal, vol. 20, no. 14, pp. 2633-2635, 2006.

[74] S. D. Allister, C. Chan, R. J. Taft et al., "Cannabinoids selectively inhibit proliferation and induce death of cultured human glioblastoma multiforme cells," Journal of Neuro-Oncology, vol. 74, no. 1, pp. 31-40, 2005.

[75] M. Bifulco, C. Laezza, G. Portella et al., "Control by the endogenous cannabinoid system of ras oncogene-dependent tumor growth," FASEB Journal, vol. 15, no. 14, pp. 2745-2747, 2001.

[76] A. Carracedo, M. Gironella, M. Lorente et al., "Cannabinoids induce apoptosis of pancreatic tumor cells via endoplasmic reticulum stress-related genes," Cancer Research, vol. 66, no. 13, pp. 6748-6755, 2006.

[77] K. Gustafsson, B. Christensson, B. Sander, and J. Flygare, "Cannabinoid receptor-mediated apoptosis induced by $R(+)$-methanandamide and Win55,212-2 is associated with ceramide accumulation and p38 activation in mantle cell lymphoma," Molecular Pharmacology, vol. 70, no. 5, pp. 1612-1620, 2006.

[78] S. Sarfaraz, F. Afaq, V. M. Adhami, and H. Mukhtar, "Cannabinoid receptor as a novel target for the treatment of prostate cancer," Cancer Research, vol. 65, no. 5, pp. 1635-1641, 2005.

[79] M. M. Caffarel, D. Sarrió, J. Palacios, M. Guzmán, and C. Sánchez, " $\Delta$ 9-tetrahydrocannabinol inhibits cell cycle progression in human breast cancer cells through Cdc2 regulation," Cancer Research, vol. 66, no. 13, pp. 6615-6621, 2006.

[80] T. C. Islam, A. C. Asplund, J. M. Lindvall et al., "High level cannabinoid receptor 1 , resistance of regulator $\mathrm{G}$ protein signaling 13 and differential expression of Cyclin D1 in mantle cell lymphoma," Leukemia, vol. 17, no. 9, pp. 1880-1890, 2003.

[81] S. Ek, C.-M. Högerkorp, M. Dictor, M. Ehinger, and C. A. K. Borrebaeck, "Mantle cell lymphomas express a distinct genetic signature affecting lymphocyte trafficking and growth regulation as compared with subpopulations of normal human B cells," Cancer Research, vol. 62, no. 15, pp. 4398-4405, 2002.

[82] T. G. D. Pulgar, M. L. de Ceballos, M. Guzmán, and G. Velasco, "Cannabinoids protect astrocytes from ceramide-induced apoptosis through the phosphatidylinositol 3-kinase/protein kinase B pathway," Journal of Biological Chemistry, vol. 277, no. 39, pp. 36527-36533, 2002.

[83] A. Carracedo, M. J. H. Geelen, M. Diez, K. Hanada, M. Guzmán, and G. Velasco, "Ceramide sensitizes astrocytes to oxidative stress: protective role of cannabinoids," Biochemical Journal, vol. 380, part 2, pp. 435-440, 2004.

[84] E. Molina-Holgado, J. M. Vela, A. Arévalo-Martín et al., “Cannabinoids promote oligodendrocyte progenitor survival: involvement of cannabinoid receptors and phosphatidylinositol-3 kinase/Akt signaling," Journal of Neuroscience, vol. 22, no. 22, pp. 9742-9753, 2002.

[85] C. Sánchez, I. Galve-Roperh, C. Canova, P. Brachet, and M. Guzmán, " $\Delta$ 9-tetrahydrocannabinol induces apoptosis in C6 glioma cells," FEBS Letters, vol. 436, no. 1, pp. 6-10, 1998. 
[86] P. C. Schmid, L. E. Wold, R. J. Krebsbach, E. V. Berdyshev, and H. H. O. Schmid, "Anandamide and other N-acylethanolamines in human tumors," Lipids, vol. 37, no. 9, pp. 907-912, 2002.

[87] K. Nithipatikom, M. P. Endsley, M. A. Isbell et al., "2-arachidonoylglycerol: a novel inhibitor of androgen-independent prostate cancer cell invasion," Cancer Research, vol. 64, no. 24, pp. 88268830, 2004.

[88] M. P. Endsley, R. Thill, I. Choudhry et al., "Expression and function of fatty acid amide hydrolase in prostate cancer," International Journal of Cancer, vol. 123, no. 6, pp. 1318-1326, 2008.

[89] D. K. Nomura, J. Z. Long, S. Niessen, H. S. Hoover, S.-W. Ng, and B. F. Cravatt, "Monoacylglycerol lipase regulates a fatty acid network that promotes cancer pathogenesis," Cell, vol. 140, no. 1, pp. 49-61, 2010.

[90] A. Ligresti, T. Bisogno, I. Matias et al., "Possible endocannabinoid control of colorectal cancer growth," Gastroenterology, vol. 125, no. 3, pp. 677-687, 2003.

[91] C. W. Michalski, F. E. Oti, M. Erkan et al., "Cannabinoids in pancreatic cancer: correlation with survival and pain," International Journal of Cancer, vol. 122, no. 4, pp. 742-750, 2008.

[92] X. Xu, Y. Liu, S. Huang et al., "Overexpression of cannabinoid receptors $\mathrm{CB}_{1}$ and $\mathrm{CB}_{2}$ correlates with improved prognosis of patients with hepatocellular carcinoma," Cancer Genetics and Cytogenetics, vol. 171, no. 1, pp. 31-38, 2006.

[93] M. A. Jordà, N. Rayman, M. Tas et al., "The peripheral cannabinoid receptor $\mathrm{CB}_{2}$, frequently expressed on AML blasts, either induces a neutrophilic differentiation block or confers abnormal migration properties in a ligand-dependent manner," Blood, vol. 104, no. 2, pp. 526-534, 2004.

[94] J. Held-Feindt, L. Dörner, G. Sahan, H. M. Mehdorn, and R. Mentlein, "Cannabinoid receptors in human astroglial tumors," Journal of Neurochemistry, vol. 98, no. 3, pp. 886-893, 2006.

[95] C. Calatozzolo, A. Salmaggi, B. Pollo et al., "Expression of cannabinoid receptors and neurotrophins in human gliomas," Neurological Sciences, vol. 28, no. 6, pp. 304-310, 2007.

[96] S. B. Gustafsson, T. Lindgren, M. Jonsson, and S. O. P. Jacobsson, "Cannabinoid receptor-independent cytotoxic effects of cannabinoids in human colorectal carcinoma cells: synergism with 5fluorouracil," Cancer Chemotherapy and Pharmacology, vol. 63, no. 4, pp. 691-701, 2009.

[97] D. Wang, H. Wang, W. Ning, M. G. Backlund, S. K. Dey, and R. N. DuBois, "Loss of cannabinoid receptor 1 accelerates intestinal tumor growth," Cancer Research, vol. 68, no. 15, pp. 6468-6476, 2008.

[98] R. Ramer and B. Hinz, "Inhibition of cancer cell invasion by cannabinoids via increased expression of tissue inhibitor of matrix metalloproteinases-1," Journal of the National Cancer Institute, vol. 100, no. 1, pp. 59-69, 2008.

[99] G. Czifra, A. Varga, K. Nyeste et al., "Increased expressions of cannabinoid receptor-1 and transient receptor potential vanilloid-1 in human prostate carcinoma," Journal of Cancer Research and Clinical Oncology, vol. 135, no. 4, pp. 507-514, 2009.

[100] S. C. Chung, P. Hammarsten, A. Josefsson et al., "A high cannabinoid $\mathrm{CB}_{1}$ receptor immunoreactivity is associated with disease severity and outcome in prostate cancer," European Journal of Cancer, vol. 45, no. 1, pp. 174-182, 2009.

[101] C. Börner, V. Höllt, W. Sebald, and J. Kraus, “Transcriptional regulation of the cannabinoid receptor type 1 gene in T cells by cannabinoids," Journal of Leukocyte Biology, vol. 81, no. 1, pp. 336-343, 2007.
[102] C. Rousseaux, X. Thuru, A. Gelot et al., "Lactobacillus acidophilus modulates intestinal pain and induces opioid and cannabinoid receptors," Nature Medicine, vol. 13, no. 1, pp. 35-37, 2007.

[103] M. Notarnicola, C. Messa, A. Orlando et al., "Estrogenic induction of cannabinoid $\mathrm{CB}_{1}$ receptor in human colon cancer cell lines," Scandinavian Journal of Gastroenterology, vol. 43, no. 1, pp. 66-72, 2008.

[104] S. Begum, N. Emami, A. Cheung, O. Wilkins, S. Der, and P. A. Hamel, "Cell-type-specific regulation of distinct sets of gene targets by Pax3 and Pax3/FKHR," Oncogene, vol. 24, no. 11, pp. 1860-1872, 2005.

[105] E. Ryberg, H. K. Vu, N. Larsson et al., "Identification and characterisation of a novel splice variant of the human $\mathrm{CB}_{1}$ receptor," FEBS Letters, vol. 579, no. 1, pp. 259-264, 2005.

[106] M. Maccarrone, H. Valensise, M. Bari, N. Lazzarin, C. Romanini, and A. Finazzi-Agrò, "Progesterone up-regulates anandamide hydrolase in human lymphocytes: role of cytokines and implications for fertility," Journal of Immunology, vol. 166, no. 12, pp. 7183-7189, 2001.

[107] M. Maccarrone, M. Bari, M. di Rienzo, A. Finazzi-Agrò, and A. Rossi, "Progesterone activates Fatty Acid Amide Hydrolase (FAAH) promoter in human T lymphocytes through the transcription factor Ikaros: evidence for a synergistic effect of leptin," Journal of Biological Chemistry, vol. 278, no. 35, pp. 3272632732, 2003.

[108] M. Maccarrone, T. Bisogno, H. Valensise et al., "Low fatty acid amide hydrolase and high anandamide levels are associated with failure to achieve an ongoing pregnancy after IVF and embryo transfer," Molecular Human Reproduction, vol. 8, no. 2, pp. 188-195, 2002.

[109] A. Rebollo and C. Schmitt, "Ikaros, aiolos and helios: transcription regulators and lymphoid malignancies," Immunology \& Cell Biology, vol. 81, no. 3, pp. 171-175, 2003.

[110] M. Maccarrone, V. Gasperi, F. Fezza, A. Finazzi-Agrò, and A. Rossi, "Differential regulation of fatty acid amide hydrolase promoter in human immune cells and neuronal cells by leptin and progesterone," European Journal of Biochemistry, vol. 271, no. 23-24, pp. 4666-4676, 2004.

[111] Y. Guo, H. Wang, Y. Okamoto et al., "N-acylphosphatidylethanolamine-hydrolyzing phospholipase D is an important determinant of uterine anandamide levels during implantation," Journal of Biological Chemistry, vol. 280, no. 25, pp. 2342923432, 2005.

[112] M. Maccarrone, M. de Felici, M. Bari, F. Klinger, G. Siracusa, and A. Finazzi-Agrò, "Down-regulation of anandamide hydrolase in mouse uterus by sex hormones," European Journal of Biochemistry, vol. 267, no. 10, pp. 2991-2997, 2000.

[113] M. L. Ribeiro, C. A. Vercelli, M. S. Sordelli et al., "17 $\beta$-oestradiol and progesterone regulate anandamide synthesis in the rat uterus," Reproductive BioMedicine Online, vol. 18, no. 2, pp. 209218, 2009.

[114] N. M. Tsutahara, Y. S. Weems, J. A. Arreguin-Arevalo et al., "Effects of endocannabinoid 1 and $2\left(\mathrm{CB}_{1} ; \mathrm{CB}_{2}\right)$ receptor agonists on luteal weight, circulating progesterone, luteal mRNA for luteinizing hormone (LH) receptors, and luteal unoccupied and occupied receptors for $\mathrm{LH}$ in vivo in ewes," Prostaglandins \& Other Lipid Mediators, vol. 94, no. 1-2, pp. 17-24, 2011.

[115] O. M. H. Habayeb, S. C. Bell, and J. C. Konje, "Endogenous cannabinoids: metabolism and their role in reproduction," Life Sciences, vol. 70, no. 17, pp. 1963-1977, 2002.

[116] A. Shrivastava, P. M. Kuzontkoski, J. E. Groopman, and A. Prasad, "Cannabidiol induces programmed cell death in breast 
cancer cells by coordinating the cross-talk between apoptosis and autophagy," Molecular Cancer Therapeutics, vol. 10, no. 7, pp. 1161-1172, 2011.

[117] T. Karasu, T. H. Marczylo, M. Maccarrone, and J. C. Konje, “The role of sex steroid hormones, cytokines and the endocannabinoid system in female fertility," Human Reproduction Update, vol. 17, no. 3, pp. 347-361, 2011.

[118] M. Maccarrone, M. Bari, N. Battista, and A. Finazzi-Agrò, "Estrogen stimulates arachidonoylethanolamide release from human endothelial cells and platelet activation," Blood, vol. 100, no. 12, pp. 4040-4048, 2002.

[119] M. Maccarrone, K. Falciglia, M. di Rienzo, and A. Finazzi-Agrò, "Endocannabinoids, hormone-cytokine networks and human fertility," Prostaglandins Leukotrienes and Essential Fatty Acids, vol. 66, no. 2-3, pp. 309-317, 2002.

[120] E. Bloch, B. Thysen, G. A. Morrill, E. Gardner, and G. Fujimoto, "Effects of cannabinoids on reproduction and development," Vitamins and Hormones, vol. 36, pp. 203-258, 1979.

[121] S. González, G. Mauriello-Romanazzi, F. Berrendero, J. A. Ramos, M. Fosca Franzoni, and J. Fernández-Ruiz, "Decreased cannabinoid $\mathrm{CB}_{1}$ receptor mRNA levels and immunoreactivity in pituitary hyperplasia induced by prolonged exposure to estrogens," Pituitary, vol. 3, no. 4, pp. 221-226, 2000.

[122] J. Ferlay, H.-R. Shin, F. Bray, D. Forman, C. Mathers, and D. M. Parkin, "Estimates of worldwide burden of cancer in 2008: GLOBOCAN 2008," International Journal of Cancer, vol. 127, no. 12, pp. 2893-2917, 2010.

[123] M. P. Madigan, R. G. Ziegler, J. Benichou, C. Byrne, and R. N. Hoover, "Proportion of breast cancer cases in the United States explained by well-established risk factors," Journal of the National Cancer Institute, vol. 87, no. 22, pp. 1681-1685, 1995.

[124] T. A. Guise, A. Brufsky, and R. E. Coleman, "Understanding and optimizing bone health in breast cancer," Current Medical Research and Opinion, vol. 26, supplement 3, pp. 3-20, 2010.

[125] K. Pantel and C. Alix-Panabières, "Circulating tumour cells in cancer patients: challenges and perspectives," Trends in Molecular Medicine, vol. 16, no. 9, pp. 398-406, 2010.

[126] A. G. Glass, J. V. Lacey Jr., J. D. Carreon, and R. N. Hoover, "Breast cancer incidence, 1980-2006: combined roles of menopausal hormone therapy, screening mammography, and estrogen receptor status," Journal of the National Cancer Institute, vol. 99, no. 15, pp. 1152-1161, 2007.

[127] Z. Qamri, A. Preet, M. W. Nasser et al., "Synthetic cannabinoid receptor agonists inhibit tumor growth and metastasis of breast cancer," Molecular Cancer Therapeutics, vol. 8, no. 11, pp. 31173129, 2009.

[128] M. M. Caffarel, C. Andradas, E. Mira et al., "Cannabinoids reduce ErbB2-driven breast cancer progression through Akt inhibition," Molecular Cancer, vol. 9, article 196, 2010.

[129] D. Sarnataro, C. Grimaldi, S. Pisanti et al., "Plasma membrane and lysosomal localization of $\mathrm{CB}_{1}$ cannabinoid receptor are dependent on lipid rafts and regulated by anandamide in human breast cancer cells," FEBS Letters, vol. 579, no. 28, pp. 6343-6349, 2005.

[130] A. Ligresti, A. S. Moriello, K. Starowicz et al., "Antitumor activity of plant cannabinoids with emphasis on the effect of cannabidiol on human breast carcinoma," Journal of Pharmacology and Experimental Therapeutics, vol. 318, no. 3, pp. 1375-1387, 2006.

[131] T. Bisogno, K. Katayama, D. Melck et al., "Biosynthesis and degradation of bioactive fatty acid amides in human breast cancer and rat pheochromocytoma cells-implications for cell proliferation and differentiation," European Journal of Biochemistry, vol. 254, no. 3, pp. 634-642, 1998.

[132] S. Takeda, S. Yamaori, E. Motoya et al., " $\Delta 9$-tetrahydrocannabinol enhances MCF-7 cell proliferation via cannabinoid receptor-independent signaling," Toxicology, vol. 245, no. 1-2, pp. 141146, 2008.

[133] L. A. Ford, A. J. Roelofs, S. Anavi-Goffer et al., "A role for L- $\alpha-$ lysophosphatidylinositol and GPR55 in the modulation of migration, orientation and polarization of human breast cancer cells," British Journal of Pharmacology, vol. 160, no. 3, pp. 762771, 2010.

[134] C. Grimaldi, S. Pisanti, C. Laezza et al., "Anandamide inhibits adhesion and migration of breast cancer cells," Experimental Cell Research, vol. 312, no. 4, pp. 363-373, 2006.

[135] S. D. McAllister, R. T. Christian, M. P. Horowitz, A. Garcia, and P.-Y. Desprez, "Cannabidiol as a novel inhibitor of Id-1 gene expression in aggressive breast cancer cells," Molecular Cancer Therapeutics, vol. 6, no. 11, pp. 2921-2927, 2007.

[136] G. Z. Huang and C. S. Woolley, "Estradiol acutely suppresses inhibition in the hippocampus through a sex-specific endocannabinoid and mGluR-dependent mechanism," Neuron, vol. 74, no. 5, pp. 801-808, 2012.

[137] A. H. Taylor, J. H. Pringle, S. C. Bell, and F. Al-Azzawi, "Specific inhibition of estrogen receptor alpha function by antisense oligodeoxyribonucleotides," Antisense and Nucleic Acid Drug Development, vol. 11, no. 4, pp. 219-231, 2001.

[138] A. H. Taylor, F. Al-Azzawi, J. H. Pringle, and S. C. Bell, "Inhibition of endometrial carcinoma cell growth using antisense estrogen receptor oligodeoxyribonucleotides," Anticancer Research, vol. 22, no. 6, pp. 3993-4003, 2002.

[139] M. Djulbegovic, R. J. Beyth, M. M. Neuberger et al., "Screening for prostate cancer: systematic review and meta-analysis of randomised controlled trials," British Medical Journal, vol. 341, article c4543, 2010.

[140] F. H. Schröder, J. Hugosson, M. J. Roobol et al., "Screening and prostate-cancer mortality in a randomized european study," The New England Journal of Medicine, vol. 360, no. 13, pp. 1320-1328, 2009.

[141] L. Ruiz, A. Miguel, and I. Díaz-Laviada, “ $\Delta 9$-tetrahydrocannabinol induces apoptosis in human prostate PC-3 cells via a receptor-independent mechanism," FEBS Letters, vol. 458, no. 3, pp. 400-404, 1999.

[142] I. Brown, M. G. Cascio, K. W. J. Wahle et al., "Cannabinoid receptor-dependent and -independent anti-proliferative effects of omega-3 ethanolamides in androgen receptor-positive and -negative prostate cancer cell lines," Carcinogenesis, vol. 31, no. 9, pp. 1584-1591, 2010.

[143] L. Thors, A. Bergh, E. Persson et al., "Fatty acid amide hydrolase in prostate cancer: association with disease severity and outcome, $\mathrm{CB}_{1}$ receptor expression and regulation by IL-4," PLoS ONE, vol. 5, no. 8, Article ID e12275, 2010.

[144] R. Pĩeiro, T. Maffucci, and M. Falasca, “The putative cannabinoid receptor GPR55 defines a novel autocrine loop in cancer cell proliferation," Oncogene, vol. 30, no. 2, pp. 142-152, 2011.

[145] D. Owerbach, W. J. Rutter, and N. E. Cooke, "The prolactin gene is located on chromosome 6 in humans," Science, vol. 212, no. 4496, pp. 815-816, 1981.

[146] P. A. Kelly, J. Djiane, M.-C. Postel-Vinay, and M. Edery, “The prolactin/growth hormone receptor family," Endocrine Reviews, vol. 12, no. 3, pp. 235-251, 1991. 
[147] M. Mimeault, N. Pommery, N. Wattez, C. Bailly, and J.-P. Hénichart, "Anti-proliferative and apoptotic effects of anandamide in human prostatic cancer cell lines: implication of epidermal growth factor receptor down-regulation and ceramide production," Prostate, vol. 56, no. 1, pp. 1-12, 2003.

[148] S. Sarfaraz, F. Afaq, V. M. Adhami, A. Malik, and H. Mukhtar, "Cannabinoid receptor agonist-induced apoptosis of human prostate cancer cells LNCaP proceeds through sustained activation of ERK1/2 leading to G 1 cell cycle arrest," Journal of Biological Chemistry, vol. 281, no. 51, pp. 39480-39491, 2006.

[149] F. Amant, P. Moerman, P. Neven, D. Timmerman, E. van Limbergen, and I. Vergote, "Endometrial cancer," The Lancet, vol. 366, no. 9484, pp. 491-505, 2005.

[150] Cancer Research UK, Cancer Statistics, 2011.

[151] L. Dossus, N. Allen, R. Kaaks et al., "Reproductive risk factors and endometrial cancer: the European prospective investigation into cancer and nutrition," International Journal of Cancer, vol. 127, no. 2, pp. 442-451, 2010.

[152] R. Kaaks, A. Lukanova, and M. S. Kurzer, "Obesity, endogenous hormones, and endometrial cancer risk: a synthetic review," Cancer Epidemiology Biomarkers \& Prevention, vol. 11, no. 12, pp. 1531-1543, 2002.

[153] F. Modugno, R. B. Ness, C. Chen, and N. S. Weiss, "Inflammation and endometrial cancer: a hypothesis," Cancer Epidemiology Biomarkers \& Prevention, vol. 14, no. 12, pp. 2840-2847, 2005.

[154] J. A. Doherty, K. L. Cushing-Haugen, B. S. Saltzman et al., "Long-term use of postmenopausal estrogen and progestin hormone therapies and the risk of endometrial cancer," American Journal of Obstetrics and Gynecology, vol. 197, no. 2, pp. 139.el139.e7, 2007.

[155] G. Halis and A. Arici, "Endometriosis and inflammation in infertility," Annals of the New York Academy of Sciences, vol. 1034, pp. 300-315, 2004.

[156] N. Chegini, "Proinflammatory and profibrotic mediators: principal effectors of leiomyoma development as a fibrotic disorder," Seminars in Reproductive Medicine, vol. 28, no. 3, pp. 180-203, 2010.

[157] D. E. Soper, "Pelvic inflammatory disease," Obstetrics and Gynecology, vol. 116, no. 2, part 1, pp. 419-428, 2010.

[158] C. L. Walker and E. A. Stewart, "Uterine fibroids: the elephant in the room," Science, vol. 308, no. 5728, pp. 1589-1592, 2005.

[159] N. F. Vlahos, K. P. Economopoulos, and S. Fotiou, "Endometriosis, in vitro fertilisation and the risk of gynaecological malignancies, including ovarian and breast cancer," Best Practice \& Research, vol. 24, no. 1, pp. 39-50, 2010.

[160] S. F. Lax, E. S. Pizer, B. M. Ronnett, and R. J. Kurman, "Comparison of estrogen and progesterone receptor, $\mathrm{Ki}-67$, and p53 immunoreactivity in uterine endometrioid carcinoma and endometrioid carcinoma with squamous, mucinous, secretory, and ciliated cell differentiation," Human Pathology, vol. 29, no. 9, pp. 924-931, 1998.

[161] M. K. Oehler, A. Brand, and G. V. Wain, "Molecular genetics and endometrial cancer," Journal of the British Menopause Society, vol. 9, no. 1, pp. 27-31, 2003.

[162] M. Guida, A. Ligresti, D. de Filippis et al., "The levels of the endocannabinoid receptor $\mathrm{CB}_{2}$ and its ligand 2-arachidonoylglycerol are elevated in endometrial carcinoma," Endocrinology, vol. 151, no. 3, pp. 921-928, 2010.

[163] M. Guzmán, C. Sánchez, and I. Galve-Roperh, "Cannabinoids and cell fate," Pharmacology \& Therapeutics, vol. 95, no. 2, pp. 175-184, 2002.
[164] R. J. McKallip, C. Lombard, M. Fisher et al., “Targeting $\mathrm{CB}_{2}$ cannabinoid receptors as a novel therapy to treat malignant lymphoblastic disease," Blood, vol. 100, no. 2, pp. 627-634, 2002. 


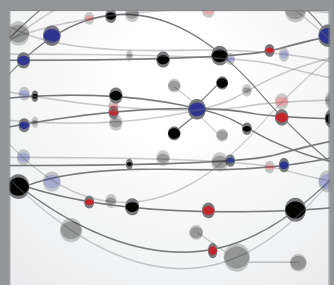

The Scientific World Journal
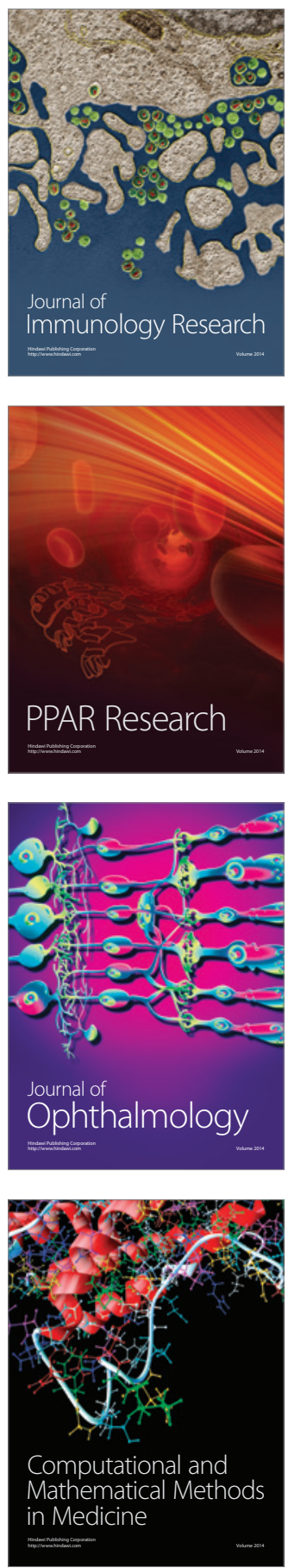

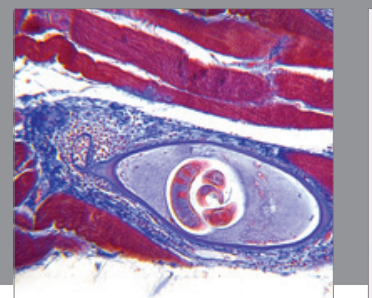

Gastroenterology

Research and Practice
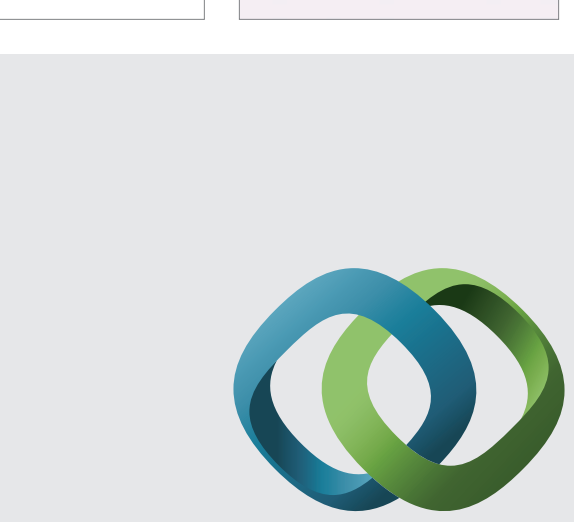

\section{Hindawi}

Submit your manuscripts at

http://www.hindawi.com
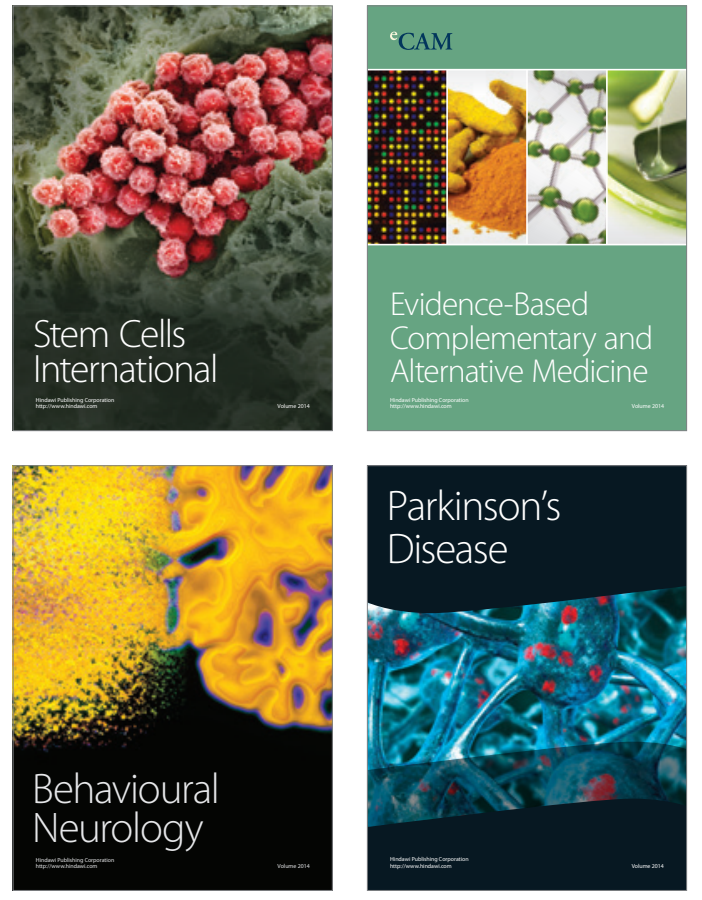
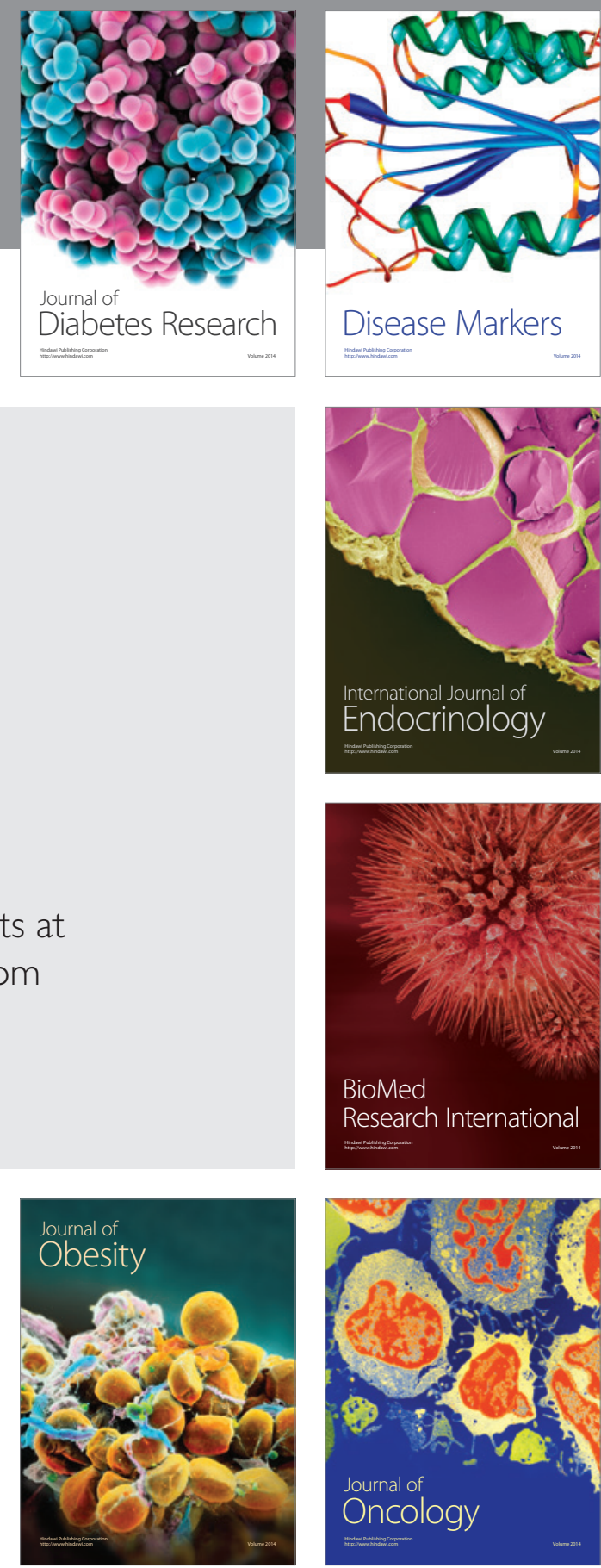

Disease Markers
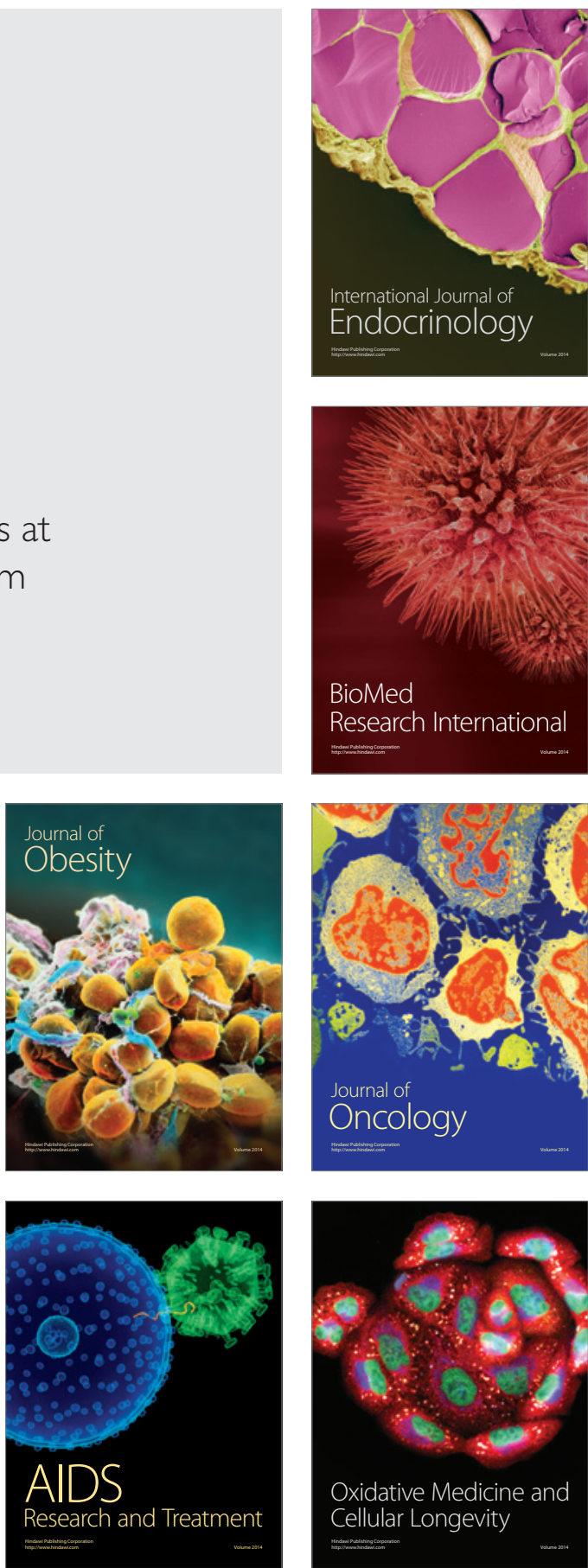